\title{
CASE COMMENT: PARTIAL PRIVILEGE \\ AND FULL DISCLOSURE IN CIVIL ACTIONS: M.(A.) v. RYAN
}

\section{JUNE ROSS*}

M.(A.) v. Ryan' was handed down by the Supreme Court of Canada on the same day as the much more highly publicized $R$. v. Carosella. ${ }^{2}$ The case was a civil version of $R$. v. $O^{\prime}$ Connor, ${ }^{3}$ a contested application for disclosure of therapeutic records raising issues of the competing values of disclosure and privacy, in the course of a damages suit, rather than a criminal trial. The Court held that the documents were protected by a partial privilege, a form of common law privilege which applies to communications that occur between psychiatrist and patient, or in the course of other confidential relationships. Nonetheless, the Court upheld the decision of the British Columbia Court of Appeal, which had held that the documents were not privileged and had ordered production of a significant part of the records. This comment will address the rationale for and implications of this apparent contradiction.

McLachlin J. wrote for six of the seven justices hearing the appeal; ${ }^{4} \mathrm{~L}$ 'HeureuxDubé J. dissented in the result, but expressed agreement with much that was said by the majority. All of the justices were agreed that psychiatrist/patient communications should not be protected by an absolute privilege, that these communications would have an obvious relevance in cases in which a sexual assault victim sues for the psychological injury inflicted by the assault, and that the public interest in the proper administration of justice supports, if not compels, discovery of such relevant information. ${ }^{5}$ In civil actions, for the judiciary, it seems that the production of therapeutic records of sexual assault victims is not a very divisive or controversial issue.

Associate Professor, University of Alberta, Faculty of Law.

M.(A.) v. Ryan (1997), 143 D.L.R. (4th) 1 (S.C.C.) [hereinafter Ryan (S.C.C.)], aff'g [1995] 1

W.W.R. 677 (B.C.C.A.) [hereinafter Ryan (B.C.C.A.)], rev'g in part [1993] 7 W.W.R. 480

(B.C.S.C.) [hereinafter Ryan (B.C.S.C.)], aff'g [1993] B.C.W.L.D. 1680 (Master).

(1997), 112 C.C.C. (3d) 289 (S.C.C.); see W. Renke, "Records Lost, Rights Found: $R$ v. Carosella" (1997) 35 Alta. L. Rev. 1083.

(1995), (1996) 103 C.C.C. (3d) I (S.C.C.) [hereinafter O'Connor].

La Forest, Sopinka, Cory, Iaccobucci and Major JJ. concurred.

The case for disclosure has been made many times, notably in Cook v. Ip (1985), (1986) 22 D.L.R.

(4th) 1 at 4 (Ont. C.A.), in which Cory J.A. (as he then was) held:

There can be no doubt that it is in the public interest to ensure that all relevant evidence is available to the court. This is essential if justice is to be done between the parties.... The production of medical records is ... fundamental to a court's determination of the nature, extent and effect of the injuries and the appropriate measure of damages flowing from them. It is also important to the parties that they have early production of these documents. Settlement of disputes at an early date is of great benefit to the parties and to the judicial system. In order to make an informed, fair and just settlement, counsel for the parties must be in possession of all pertinent material. 
A sharply contrasting view may be held by the persons subject to such discovery. ${ }^{6}$ The discovery process may be experienced as unduly and offensively intrusive, as an aggressive strategic ploy, and as a form of character assassination. The process of proving damages with its inherent scepticism may appear callous and even discriminatory. On the other hand, a damages lawsuit, in which compensation may be claimed for injury assessed in an individualized and comprehensive way, offers both economic and symbolic benefits to the plaintiff.

This comment will review the holding in Ryan, discuss implications of the decision for future cases, and finally, inquire into whether the decision responds to concerns and perspectives such as those described above.

The following is an excerpt from a Globe and Mail report in which the plaintiff in Doe $\mathbf{v}$. Metropolitan Toronto (Municipality) Commissioners of Police (1990), 74 O.R. (2d) 225 (Div. Ct.), leave to appeal denied 1 O.R. (3d) 416 (C.A.), gives her perspective on the discovery process: Eleven years after she was raped at knifepoint by Toronto's notorious Balcony Rapist, a woman is finding that her decade-old lawsuit against the city's police is taking a nasty turn. In trying to minimize any award of damages, lawyers for the police board have opted for a strategy popular among counsel for accused rapists: obtaining the woman's psychiatric records to discover whether previous abuse left her emotionally damaged. "It's called the damaged-goods theory," said the small, slight, 45 year-old woman who is Jane Doe in the groundbreaking lawsuit Jane Doe and Metro Toronto Board of Police Commissioners. "The criminal act of a rape could not damage what was already damaged."... [A]fter six years of pretrial hearings, she is preparing to go to trial in September, when she will ask the court to establish just how much police should pay if a woman is raped because their negligence left her vulnerable. But in seeking $\$ 600,000$ in damages, she has become vulnerable once more.... [B]ecause she is arguing that her life was shattered by the rape, her emotional, sexual, financial and family history can be reviewed. She has spent two full days being tested and interviewed by psychologists and psychiatrists who developed a profile of her for the police board, she said. The interview included questions about her sexual history. Lawyers for the police board also obtained notes from sessions she had with psychiatrists before and after the rape, she said. They obtained her income-tax records and her health-insurance records. "Everyone says to me, 'But they can't do that. Why would they be allowed to do that?' It's so sad and so ironic because, in fact, it is done every day. Their defence is to attack my character." ... She bristles when asked how the rape damaged her life. "It's like saying, 'How did having your arm cut off damage your life?' There are damages inherent in the crime of rape." ... Even so, she goes on to describe how the rape changed her life. "The biggest change for me was the loss of the joy of life." She said she could no longer trust men, felt "total and complete fear" in simply walking to the comer store for cigarettes, would suspect men passing her on the sidewalk of preparing to jump her. She said she had been on the threshold of a career in film and video, but lost her confidence and her sense of purpose.... She said she developed anxiety and sleeping problems, and although she resisted taking medication for about two years, eventually went on antidepressants. "Rape is part robbery, part murder. Your identity is stolen from you, and a portion of you ceases to exist." ... If she wins her lawsuit, she said, she will have "closure," both in her political fight and in dealing with the pain of the rape. But no matter how the suit ends, she said, "I believe I have won in doing it." (S. Fine, "Woman Suing Police Finds Past Spotlighted" Globe and Mail (7 July 1997) A1.) 


\section{THE CASE AND THE APPLICATION FOR PRODUCTION IN THE COURTS OF BRITISH COLUMBIA}

A.M. was the appellant in the Supreme Court of Canada and the plaintiff in the action. During the years 1971 to 1972 , when A.M. was 17 years old, she was a patient of Dr. Ryan, a psychiatrist. She sued for damages resulting from sexual assault and acts of gross indecency committed during the course of her treatment by him. She claimed that these actions caused her to suffer mental distress, loss of self-esteem, difficulty forming and maintaining relationships, psychological trauma and depression, and foregone career and educational opportunities. ${ }^{7}$

The defendant admitted the acts, but claimed they were consensual. He further denied that the plaintiff suffered the damages claimed or that his acts caused or contributed to them.

In 1986 the plaintiff had commenced psychiatric treatment with Dr. Parfitt. The defendant sought access to the records of this therapy, bringing an application against Dr. Parfitt for the production of documents in the possession or control of a non-party. ${ }^{8}$ In the British Columbia courts this application was contested by Dr. Parfitt, with the plaintiff assuming a supportive role only. However, the plaintiff appealed the order for production to the Supreme Court of Canada.

At each level the defendant's application was largely successful, although some limits and conditions were placed on production at the levels of the Court of Appeal and the Supreme Court of Canada. The initial Master's order, upheld by the British Columbia Supreme Court, required the production by Dr. Parfitt of all records in her possession regarding the plaintiff's treatment. Before the Court of Appeal, the nature of the records was categorized into three types:

(1) notes by Dr. Parfitt to herself, written in the patient's presence, recording some but not all of their discussions; notes by Dr. Parfitt to herself, attempting to "make sense" of what the patient had told her;

reporting letters to the patient's family doctor.'

7 The Statement of Claim is reproduced in the Court of Appeal judgment, Ryan (B.C.C.A.), supra note 1 at 680 (para. 2).

8 British Columbia Supreme Court Rules, r. 26(11). An alternative procedure would have been to seek production through the plaintiff, as the records were in her control (ibid. at 688 (paras. 1920)), relying on Mclnerney v. MacDonald, [1992] 2 S.C.R. 138). For the Alberta position, see G.H. Poelman, "Discovery Procedure and Practice: Recent Developments" (1996) 34 Alta. L. Rev. 352.

9 Ryan (B.C.C.A.), ibid. at 687 (para. 13). 
Production of letters in the third category was not disputed. The Court of Appeal ordered production of notes in the first, but not the second category. ${ }^{10}$ The Court also imposed conditions on the production to protect the confidentiality of the notes to the greatest extent possible, while still permitting their use for discovery purposes. These conditions were:

(1) The defendant's solicitors and expert witness might examine the notes, but the defendant himself could not, except with court leave;

(2) No person who examined the notes should disclose their contents to others;

(3) No person who examined the notes should make any use of them, save for purposes of the action;

(4) The defendant's solicitors should receive one copy of the notes, and were not permitted to photocopy them."

The essential position of Dr. Parfitt before the British Columbia courts and the plaintiff before the Supreme Court of Canada was that because of the confidential nature of the psychiatrist/patient relationship and the nature of the notes whose production was sought, the documents should be characterized as privileged and production denied. ${ }^{12}$ The consideration of the privilege claim was avoided by both the Master and the Court of Appeal, for reasons that arose from the plaintiff's originally rather limited role in the proceedings. As respondent to the application, Dr. Parfitt provided affidavit evidence to support the claim of privilege, and this claim was advanced by her counsel. Counsel for the plaintiff appeared and/or supported this position, but the plaintiff did not provide an affidavit or otherwise formalize her claim of privilege. The Master held that the lack of evidence from the plaintiff meant that Wigmore's first criterion of privilege, that the "communications must originate in a confidence that they will not be disclosed," had not been demonstrated. ${ }^{13}$ The Court of Appeal likewise held that the plaintiff's failure to claim privilege personally was fatal to the privilege claim. ${ }^{14}$

Ibid. at 695 (para. 50).

Ibid.

It was also argued that the notes were irrelevant (ibid. at 687 (para. 14)).

Wigmore on Evidence, vol. 8, McNaughton rev. (Boston: Little, Brown, 1961) para. 2285.

Ryan (B.C.C.A.), supra note 1 at 688 (para. 16). In the British Columbia Supreme Court the privilege claim was considered and the first three of Wigmore's requirements of privilege found to have been met on the basis of Dr. Parfitt's evidence and representations. However, at the fourth stage of the test, balancing the injury to the confidential relationship against the benefit to the litigation, the fact that the plaintiff had commenced the action, and that the documents might contain relevant information, was conclusive that discovery should be ordered. The Justice's reasoning on this point may have been intended as a balancing of interests, but the language used was not consistent with balancing. One side of the balance (the injury to the relationship) was not discussed. Further, a great deal of emphasis was placed on the choice to litigate. Implicitly, this choice was treated as a waiver of privilege:

The plaintiff has initiated these proceedings to recover damages from the defendant. It is she who has chosen to place in issue a number of matters, including the issue 
In the Supreme Court of Canada, McLachlin J. for the majority ${ }^{15}$ held that privilege could only be lost by waiver. The plaintiff's conduct did not amount to a waiver. Her support of Dr. Parfitt's position made it clear no waiver was intended. The plaintiff was not called on to do more in the circumstances, as the motion for production was not directed at her. ${ }^{16}$

While the Court of Appeal did not consider the privilege claim, it did address the confidential nature of the documents in exercising its discretion under the Rules to order production of documents in the hands of a non-party. ${ }^{17}$ This discretion called on the court to consider whether production would have such an adverse effect upon the plaintiff as to make it unjust. ${ }^{18}$ The Court described the discretion to deal with privacy concerns in broad terms:

of consent upon which Dr. Parfitt's notes may contain relevant material. As well, on the issue of the quantum of damages it seems to me her notes may be extremely important ... There is no doubt that it is in the public interest to ensure all relevant evidence is before the Court on all issues. It is essential to do justice as between the parties. The public interest in the proper administration of justice outweighs the privilege where the plaintiff has placed in issue matters that probably are referred to ... (Ryan (B.C.S.C.), supra note 1 at 483 (para. 13)).

L'Heureux-Dubé J. concurred on this point; Ryan (S.C.C.), supra note 1 at 17 (para. 45).

In addition, the commencement of the action for psychological injuries did not result in an implied waiver of privilege. McLachlin $\mathrm{J}$. addressed this point very briefly at a later point in her judgment. It had been argued that by commencing proceedings the plaintiff "forfeited her right to confidentiality." McLachlin J. held that "a litigant must accept such intrusions upon her privacy as are necessary to ... get to the truth," but the lawsuit was not "a licence to delve into private aspects of her life which need not be probed for the proper disposition of the litigation." The effect of this brief holding was elaborated upon by L'Heureux-Dubé J.:

The respondent has argued that the appellant waived her right to privacy by putting her psychological well-being at issue in a trial. I do not agree. As my colleague McLachlin J. has found, her privacy is not waived by the mere fact that an action was instituted. Rather, the appellant has engaged a process where the reasonable expectation of privacy must be balanced against society's need to ensure that such litigation be conducted fairly and effectively. This may mean that a respect for Charter values in the discovery procedures would tolerate greater access to certain information, but it will not mean that her reasonable expectation of privacy has in any way been relinquished.... As such, it must be balanced with the other interests which arise in the discovery aspect of civil litigation (ibid. at 29-30 (para. 83)).

Although the majority judgment is not clear, this would seem to dispose of the question as to whether an action is an implied waiver of the right to confidentiality, which lies at the heart of the privilege affirmed by the majority. See for a discussion of this issue E. Picard \& G. Robertson, Legal Liability of Doctors and Hospitals in Canada, 3d ed. (Toronto: Carswell, 1996) at 26-27. Ryan (B.C.C.A.), supra note 1 at $692-93$ (para. 40); relying on Dufault v. Stevens (1978), 6 B.C.L.R. 199 at 203-205 (C.A.). Alberta courts exercise a similar discretion under r. 209 (Ed Miller Sales and Rentals Lid. v. Caterpillar Tractor Co. (1988), (1989) 63 Alta. L.R. (2d) 189 (Q.B.)).

In Dufault v. Stevens, ibid., the concern regarding adverse effect was directed to effects on the non-party from whom production was sought. This is consistent with Alberta jurisprudence regarding r. 209. As is evident from the quote that follows in the text, the Court of Appeal defined its discretion in broader terms, as applicable to production in the hands of a party or non-party, and would permit consideration of impact on the parties as well as non-parties. 
In considering whether to make an order compelling disclosure of private documents, whether in possession of a party or a non-party, the Court ought to ask itself whether the particular invasion of privacy is necessary to the proper administration of justice and, if so, whether some terms are appropriate to limit that invasion. There need not be a privilege against testimony in the classic sense for this to be a relevant question. By 'private documents' I mean documents which are not public documents. I do not limit this question to what might be thought of as personally embarrassing documents. ${ }^{19}$

The terms of production ordered by the Court of Appeal indicate that confidentiality concerns were addressed in two ways. First, there was a somewhat more careful approach to relevance than would normally be adopted in the discovery context. Dr. Parfitt's notes in the second category described above were excluded from production. These notes apparently reflected on the content of the notes in the first category, and as such might include at least some relevant information, but as a category their relevance was less secure. The Court had been advised by counsel that Dr. Parfitt would not be called as an expert witness on behalf of the plaintiff, and excluded these notes from production on the basis that "her diagnoses ... are of no moment." 20

The second way in which confidentiality was addressed was by terms of production designed to ensure that only those persons who required access to the notes for purposes of the litigation obtained them, and that they used them for purposes of the litigation only. These provisions, set out above, build on the implied undertaking that applies to all information obtained through the discovery process, which is now generally recognized in Canadian law.'

While this treatment does accord some accommodation of privacy concerns, it did not purport to nor did it provide a particularly increased degree of protection for the counselling records that were the subject of this application. A somewhat heightened review of relevance is commonly employed with regard to medical information and other private information. ${ }^{22}$ Assurance that discovery information is kept confidential by those with access to it, and is used for purposes of the action only, is the norm. The

Ryan (B.C.C.A.), supra note 1 at 694 (para. 45).

Ibid. at 695 (para. 50).

21 For the Alberta position, see Wirth Lid. v. Acadia Pipe \& Supply Corp. (1991), 79 Alta. L.R (2d) 345 (Q.B.). For the Ontario position, and a recent view of the case law, see Goodman v. Rossi (1995), 125 D.L.R. (4th) 613 (Ont. C.A.). The implied undertaking was not recognized in British Columbia at the time of the Court of Appeal judgment, although it now is (Hunt v. $T \& N$, [1995] 5 W.W.R. 518 (B.C.C.A.), overturning Kyoquot Logging Ltd. v. B.C. Forest Prod. Ltd., [1986] 5 W.W.R. 481 (B.C.C.A.)). However, confidentiality and proper use of discovery information could be protected by specific court order, as occurred in this case. regarding production of a personal diary. Discretionary control of the discovery of documents with a view to protecting privacy is reviewed in Frenelte v. Metropolitan Life Insurance Co. (1992), 89 D.L.R. (4th) 653 (S.C.C.), which was relied upon by L'Heureux-Dube J. in Ryan (S.C.C.), supra note 1 at 27 (para. 73). Frenette dealt with production under the civil law of Quebec, but included a comparative review of common law discovery pertaining to medical information at 68187. 
only unusual provision was the restriction on access to the documents by the defendant personally. ${ }^{23}$

\section{THE DECISION OF THE SUPREME COURT OF CANADA}

\section{A. THE APPROPRIATE LEGAL CONTEXT FOR ADDRESSING CONFIDENTIALITY}

The majority in the Supreme Court of Canada made it clear that the case should be dealt with on the basis of privilege, rather than the court's discretionary control of document production, holding that where privilege applies, it "displaces any residual discretion." A consideration of privilege first, and then a residual discretion, "would be redundant and confusing." This is because privacy interests that might otherwise inform the court's exercise of discretion are fully considered in the fourth branch of the Wigmore test (as applied later in the decision). ${ }^{24}$ Further, a residual discretion could give rise to conflicting conclusions, which "would amount to a procedural rule enacted not by the Legislature but by Order in Council, trumping the common law," a "wholly inappropriate" result. $^{25}$

The dissenting judgment of L'Heureux-Dubé J., which was based on the court's residual discretion, contained a compelling response to the last point. The exercise of discretion would not "trump" the common law of privilege; it would trump only the right to discovery where privilege does not apply. The discretion discussed and applied by the dissent and by the British Columbia Court of Appeal was not a discretion to override privilege in the interests of the administration of justice, but to limit or control discovery in the interests of privacy. ${ }^{26}$

Nonetheless, the majority's other concerns, as to redundancy and confusion, remain. If privacy concerns are fully addressed in a particular case in the context of a consideration of privilege, there is no need to reconsider the same concerns in another context. This aspect of the majority's approach in Ryan seems perfectly sensible.

On the other hand, if privacy concerns are not fully addressed within the privilege doctrine, the approach of L'Heureux-Dubé J. becomes important and should be applied. Application of the dissenting approach in such cases was not excluded by the majority judgment, and is well supported by established legal principles.

This term may not have been disputed by the parties. It was not specifically discussed by either the Court of Appeal or the Supreme Court of Canada (no cross-appeal was filed with respect to the terms of production imposed by the Court of Appeal).

Ibid. at 27 (para. 76). Further, a discretion granted under procedural rules could not override the substantive right to privilege in the absence of clear statutory authorization. Schanz v. Richards (1970), 72 W.W.R. 401 (Alta. Master) held that r. 217 of the Alberta Rules of Court was ultra vires because it overruled litigation privilege. The Rules were subsequently confirmed by the Judicature Act, R.S.A. 1980, c. J-1, s. 47. 
The majority did not exclude the possibility of a residual discretion in all cases, but indicated only that "[w] $[\mathrm{w}$ here the doctrine of privilege applies, it displaces any residual discretion" (emphasis added). If a document is not privileged, there would seem to be nothing to prevent the use of a residual discretion to decline or limit discovery. Because of the flexibility of the form of privilege accorded by the majority, there may be some difficulty in determining when privilege does not apply, and when it applies but still allows controlled disclosure, as in this case. A workable dividing line can be drawn at the point of the balancing test to be undertaken in assessing privilege, which occurs at the fourth stage of the Wigmore test. ${ }^{27}$ If the balancing test is undertaken, there has been a full consideration of the interest in privacy and the effect that it should have in the circumstances, and no reference to a residual discretion is necessary. If, however, privilege is rejected prior to the balancing test, a full consideration of privacy interests has not been undertaken. In this case privacy interests should be addressed as advocated by L'Heureux-Dubé J. Her approach would thus apply where a privacy interest exists, but one of Wigmore's first three conditions is not met.

Essentially, a problem arises if and to the extent that privilege does not protect information regarding which there is a reasonable expectation of privacy. ${ }^{28}$ In these circumstances, L'Heureux-Dubé J.'s procedure is not only appropriate but also constitutionally required. It is now clear that a constitutionally protected right to privacy is affected by compelled production of at least some "private records." court exercises a discretionary power to order production of records, it must do so in a manner that respects rights and freedoms guaranteed by the Charter, including this right of privacy. ${ }^{30}$

Ibid.

For example, it requires some liberality with the Wigmore requirements to protect a private diary under the Wigmore test (although V. (K.L.) v. R.(D.G.) (1994), 118 D.L.R. (4th) 699 (B.C.C.A.) did so). Further, confidential information may be acquired by govemment authorities where there is not a clear relationship or understanding as to confidentiality. See L.G. v. P.B. (1995), [1996] O.J. No. 1600 (Ont. Prov. Ct.) (QL), in which the court held the initial requirements of the Wigmore test were not met, as there had been no assurance of confidentiality nor any relationship between the children's aid society and an investigated person. (The court also indicated that, for the same reasons, there was no reasonable expectation of privacy. On this reasoning the category of private records protected by L'Heureux-Dube J.'s approach would be very similar to those protected under the Wigmore test.)

L'Heureux-Dubé J. described her approach as relevant to production of "private records ... in which a reasonable expectation of privacy lies" which could include "medical or therapeutic records, school records, private diaries, and the activity logs prepared by social workers" (Ryan (S.C.C.), supra note 1 at 28 (para. 79), citing $O^{\prime}$ Connor, supra note 3 at 49 (para. 99), per L'Heureux-Dube J. Lamer C.J.C. and Sopinka J. for the majority expressly agreed that "a constitutional right to privacy extends to information contained in many forms of third party records" (at 17 (para. 17)). The right to equality may also be affected, as in this case; see infra note 47 and accompanying text.

Ryan (S.C.C.), supra note 1 at $22-24$ (para. 60-65). There may be some debate as to the nature or even existence of a court's discretion in ordering production of documents, as discussed by L'Heureux-Dubé J. at 24-28 (paras. 66-77). If the court order for discovery is discretionary, the discretion must be exercised consistently with the Charter (Slaight Communications Inc. v. Davidson (1989), 59 D.L.R. (4th) 416 (S.C.C.)). If the Rules of Court mandate discovery, the mandatory provision would have to be read down to provide for adequate protection of Charter rights, or be held invalid (Dagenais v. Canadian Broadcasting Corp. (1994), (1995) 120 D.L.R. 
The essential principles relied on by L'Heureux-Dubé $J$. in constructing her procedural approach to the case are not controversial. Apart from its preference to utilize the doctrine of privilege where it applies, the majority judgment implicitly supports her approach. $O^{\prime}$ Connor provides further support. The full court in $O^{\prime}$ Connor balanced the Charter right to privacy against the accused's right to make full answer and defence. ${ }^{31}$ The majority in Ryan held that Charter values of privacy and equality should inform the development of the common law of privilege. That a constitutional right to privacy exists and is affected by document production in the criminal context is thus established. That similar factors are at play in the context of civil discovery is agreed. Finally, that Charter rights and freedoms must be considered when the court exercises authority under civil Rules cannot be disputed. ${ }^{32}$ A lower court would thus be fully justified in employing L'Heureux-Dubé J.'s approach when enforcing civil discovery obligations in circumstances where privilege does not apply, but a reasonable expectation of privacy is nonetheless affected.

\section{B. PARTIAL PRIVILEGE}

The majority commenced its discussion of privilege by distinguishing "absolute or blanket privilege" and "partial privilege." The former relates to the traditional categories of common law privilege; the latter to circumstances in which claims of privilege as to documents are addressed "individually or by sub-groups on a 'case-by-case' basis." ${ }^{33}$ This continues the approach of Slavutych v. Baker, ${ }^{34} R$. v. Gruenke, ${ }^{35}$ and $R$. v. Beharriell. ${ }^{36}$ However, it is interesting to note the change in description from "case-by-case" privilege ${ }^{37}$ to "partial" privilege. When the enforcement of "partial" privilege is considered below, it will be apparent that there is more than a change in nomenclature. ${ }^{38}$

That both majority and minority justices denied the claim for an absolute or class privilege is not surprising. It is consistent with the previous case law noted above, and with the balancing of constitutional interests found in $O^{\prime}$ Connor. ${ }^{39}$ The court was not

(4th) 12 (S.C.C.)).

$O^{\prime}$ Connor, supra note 3 at 23-24 (paras. 30-34), per Lamer C.J.C. and Sopinka J.; at 67-71 (paras. 150-63), per L'Heureux-Dubé J.

32 The case law was reviewed by L'Heureux-Dube J. in ibid. at 22-23 (paras. 60-64). She concluded that the court's discretionary power under the Rules should be exercised in accordance with Charter values. There is also a case to support the actual application of the Charter, based on the grant of authority under legislation or delegated legislation, despite its exercise in the course of a civil action between private parties (J. Ross, "The Common Law of Defamation Fails to Enter the Age of the Charter" (1996) 35 Alta. L. Rev. 117 at 118-19, 121).

$33 \quad$ Ryan (S.C.C.), supra note 1 at 7 (para. 18).

34 (1975), 55 D.L.R. (3d) 224 at 228-29 (S.C.C.).

$35 \quad$ (1991), (1992) 67 C.C.C. (3d) 289 (S.C.C.).

36 (1995), (1996) 130 D.L.R. (4th) 422 (S.C.C.) (per L'Heureux-Dubé J.).

37 $\quad R$. v. Beharriell, ibid. at 440 (paras. 39-40), 453-54 (paras. 74-78); $R$. v. Gruenke, supra note 35 at 303.

38 L'Heureux-Dube J. noted the name change and referred to partial privilege as a "variation of a case-by-case privilege" (supra note 1 at 17 (para. 45), 20 (para. 54)).

39 Supra note 3. 
prepared to sacrifice justice to confidentiality, in civil lawsuits any more than in criminal trials. If a "document or class of documents must be produced to get at the truth," it must be produced despite its confidentiality. ${ }^{40}$ A clear relationship to the truth-finding process may well be easier to establish in damage suits than in criminal cases, as the issues raised include not only the occurrence of the assault, but the resulting psychological harm. ${ }^{41}$

There was also unanimity that an extended and more flexible form of privilege may be available where traditional categories of privilege do not apply. The common law has evolved to recognize privilege "in new situations where reason, experience and application of the principles that underlie the traditional privileges so dictate."42 These principles are the now familiar Wigmore conditions. ${ }^{43}$

The developing law of privilege should reflect the "social and legal realities of our time," including the wrongs perpetuated by sexual abuse, the extension of medical treatment to mental and emotional trauma, and the Charter. All of the justices agreed that the Charter provides useful direction. McLachlin J. explained that the Charter would not actually apply, as the Court was concerned with common law in civil litigation between private parties, but that the common law should nonetheless be developed in a way that "reflects Charter values."44 As discussed above, L'HeureuxDubé J. relied on the Charter as a guide to the court's exercise of discretion in ordering the production of documents. ${ }^{45}$

The first three of Wigmore's conditions were quickly found to have been met, the Court relying both on the character of psychiatrist/patient communications in general, and specific evidence as to the communications between A.M. and Dr. Parfitt. As summarized by McLachlin J., "[t]he communications were confidential. Their confidence is essential to the psychiatrist-patient relationship. The relationship itself and the treatment it makes possible are of transcendant public importance." ${ }^{46}$

Ryan (S.C.C.), supra note 1 at 12 (para. 33).

Ibid. at 32 (para. 90) (per L'Heureux-Dubé J.). See also Ryan (B.C.C.A.), supra note 1 at 693-94 (para. 44).

Ryan (S.C.C.), supra note 1 at 8 (para. 20).

Supra note 13:

(1) The communications must originate in a confidence that they will not be disclosed.

(2) This element of confidentiality must be essential to the full and satisfactory maintenance of the relation between the parties.

(3) The relation must be one which in the opinion of the community ought to be sedulously fostered.

(4) The injury that would inure to the relation by the disclosure of the communications must be greater than the benefit thereby obtained for the correct disposal of the litigation. Ryan (S.C.C.), supra note 1 at 8-9 (paras. 21-23). These concepts and the cases on which they are based are discussed in Ross, supra note 32 at 125-31.

Ryan (S.C.C.), supra note 1 at 22-24 (paras. 60-65), and see the discussion supra notes 29-33 and accompanying text.

Ibid. at 11 (para. 28). 
It was the fourth requirement, the balancing of the injury to the confidential relationship against the benefits of disclosure for the litigation, that raised the difficult issues. At this stage the Charter values of privacy and equality ${ }^{47}$ came into consideration and supported the already significant claim for confidentiality established under the first three requirements. The particular nature of the case and the evidence were important. McLachlin J. commented:

A rule of privilege which fails to protect confidential doctor/patient communications in the context of an action arising out of sexual assault perpetuates the disadvantage felt by victims of sexual assault, often women. The intimate nature of sexual assault heightens the privacy concerns of the victim and may increase, if automatic disclosure is the rule, the difficulty of obtaining redress for the wrong. The victim of a sexual assault is thus placed in a disadvantaged position as compared with the victim of a different wrong. The result may be that the victim of a sexual assault does not obtain the equal benefit of the law to which s. 15 of the Charter entitles her. She is doubly victimized, initially by the sexual assault and later by the price she must pay to claim redress - redress which in some cases may be part of her program of therapy. ${ }^{48}$

The majority judgment went on to explicitly compare the balancing under the fourth Wigmore condition with the more direct balancing of constitutional interests in $O^{\prime}$ Connor $^{49}$ The primary difference arising from the civil context referred to by the majority was that the defendant's interest in production, while of the same nature as an accused's claim to make full answer and defence, is less compelling. A potential loss of "money and repute" is not as significant as a potential loss of liberty. ${ }^{50}$ One would thus expect less, not more production in the civil context: "documents produced in a criminal case may not always be producible in a civil case, where the privacy interest of the complainant may more easily outweigh the defendant's interest in production." 51

McLachlin J. located the value of privacy in $\mathbf{s .} 8$ of the Charter. L'Heureux-Dube J. also relied on s. 7, as she had in $O^{\prime}$ Connor, supra note 3 at 53-57 (paras. 110-19) and in $R$. v. Beharriell, supra note 36 at 455 (paras. 81-82). The majority in $O^{\prime}$ Connor expressed "general agreement" or agreement with "many of her conclusions" regarding privacy and privilege (at 13 (para. 2), per Lamer C.J.C. and Sopinka J.; at 78 (para. 189), per Cory J. and Iaccobucci J.).

Ryan (S.C.C.), supra note 1 at 11-12 (para. 30), accord L'Heureux-Dubé J. at 32-33 (para. 91), who added:

[T]he wrong involved here, sexual assault, may create a need for a therapeutic response ...

[E]ffective counselling requires that the most intimate details of a patient's life and her innermost thoughts, fears, and feelings be freely shared with the therapist.

See, also $O^{\prime}$ Connor, supra note 3 at 53-54 (para. 112) and 56 (para. 119) (per L'Heureux-Dube J.) and the specific agreement of Lamer C.J.C. and Sopinka J. for the majority at 14-15 (para. 8). Where private records in the hands of a third party are sought in a criminal case, there is not a direct application of a Charter right and remedy (as there is where remedies for non-disclosure are sought) because "at the moment of the request for production, the accused's rights under the Charter have not been violated." But when ordering production, the court must balance the Charter right to full answer and defence against the Charter rights to privacy and equality ( $O$ 'Connor, supra note 3 at 50-51 (paras. 101-105) per L'Heureux-Dubé J.; see also 17-18 (paras. 15-18) per Lamer C.J.C. and Sopinka J.). Ryan (S.C.C.), supra note 1 at 14 (para. 36) per McLachlin J.; see L'Heureux-Dube J. at 30 (para. 84)). 
L'Heureux-Dubé J., however, referred to other contextual distinctions that provide support for both the defendant's entitlement to production and the reasonableness of limitations on the plaintiff's right of privacy. In a civil action, the plaintiff is seeking a personal benefit and has chosen to put her psychological injury in issue. Further, the relevance of treatment records to the assessment of damage is compelling. ${ }^{52}$

Nonetheless, the stage would seem to have been set for an approach at least as protective of privacy interests as the criminal law procedure established in $O^{\prime}$ Connor. The majority's description of the appropriate balance certainly suggests this:

\begin{abstract}
A document relevant to a defence or claim may be required to be disclosed, notwithstanding the high interest of the plaintiff in keeping it confidential. On the other hand, documents of questionable relevance or which contain information available from other sources may be declared privileged.... It must be borne in mind that in most cases, the majority of the communications between a psychiatrist and her patient will have little or no bearing on the case at bar and can safely be excluded from production. Fishing expeditions are not appropriate where there is a compelling privacy interest at stake, even at the discovery stage..$^{33}$
\end{abstract}

How does the $O^{\prime}$ Connor procedure protect privacy? The second stage of the two stage procedure is obviously the key. At the first stage, the accused must demonstrate the "likely relevance" of the documents. This requirement does not purport to address privacy; it merely ensures that a sufficient claim has been made out as to require the court to undertake the balancing test. ${ }^{54}$ Privacy is addressed at the second stage. The records are examined by the court, and relevance is weighed against privacy, to determine whether or not the record should be produced to the accused. ${ }^{55}$ Privacy may again be addressed at the stage of determining admissibility, or considering special conditions for the presentation of evidence. ${ }^{56}$ But what was sought in $O^{\prime}$ Connor and in Ryan was privacy from disclosure to the adverse participants in the litigation, and judicial inspection of the documents prior to production is the mechanism that ensures that this aspect of privacy is violated only where necessary.

The majority in Ryan indicated that a judicial examination of the documents could be employed in the civil context, but refused to require it as a "matter of law." The procedure applied in the case did not involve such an examination. Relevance sufficient to outweigh the claim for privilege was assessed by affidavit evidence addressing the general nature of the records. As such an examination could demonstrate at most likely

Ibid. at 32 (para. 90). In other parts of her judgment, McLachlin J. also commented on the plaintiff's commencement of proceedings (referred to supra note 16), and on the relevance of the records to "the critical issue of the extent to which the respondent Dr. Ryan's conduct caused the difficulties the appellant was experiencing" (at 16 (para. 41)). Ibid. at 14-15 (para. 37). Supra note 3 at 18-19 (paras. 19-21) per Lamer C.J.C. and Sopinka J. for the majority. See also Renke, supra note 2 at 1092-93. dignity and security of the person, may also be addressed. See also Renke, ibid. at 1093-94. 
relevance, or relevance of some of the information in the category, other measures to protect confidentiality were required. The measures adopted by the Court of Appeal limited the persons who could have access to the documents (to Dr. Ryan's counsel and experts, not Dr. Ryan personally) and assured that they would use them only for purposes of the litigation. ${ }^{58}$ The assessment of relevance by the Court of Appeal, and its additional conditions, were found to be sufficient acknowledgment of the partially privileged status of the documents.

In its assessment of the adequacy of the Court of Appeal's order, the majority made a startling statement:

In the end, the only persons to see the documents in question will be the lawyers for the respondent Dr. Ryan and his expert witnesses ... In short, the plaintiff's private disclosures to her psychiatrist will be disclosed only to a small group of trustworthy professionals, much in the fashion that confidential medical records may be disclosed in a hospital setting.9

Disclosure to the lawyers for an adverse party in litigation bears little in common with disclosure in a hospital setting. The defendant's counsel are professionals, and are bound by court order and ethical rules not to misuse the information, but their interests are not the plaintiff's interests. They will use the information for purposes contrary to the plaintiff's interests. This aggravates both the perceived and the actual invasion of privacy. A plaintiff may not anticipate sensitive, or perhaps even ethical use of the information. ${ }^{60}$ Her concerns are not unreasonable. The very divergence of interest, as well as the adversarial nature of the litigation process, makes it likely that disclosure of the records will sometimes have a strategic as well as a legitimate purpose. Further, during examination for discovery, questions may be asked based on the records that will be intrusive and arguably irrelevant. The fact that examination for discovery proceeds in the absence of direct or immediate judicial control adds to the likelihood that problems will arise as to the proper scope of questioning on this kind of information. ${ }^{61}$

Even the minimal degree of additional privacy that is offered by confining the disclosure to the lawyers and experts, rather than the defendant personally, may have to be set aside. This aspect of the order could create obvious difficulties in the ability of defence counsel to obtain proper instructions, and, likely for this reason, was made subject to variation by further court order. The order puts the lawyer/client relationship on a difficult footing. The lawyer is hindered in complying with the professional obligation to disclose to the client all information necessary to "enable the lawyer to properly carry out the representation," and the trust between lawyer and client may be

ss Supra note 11 and accompanying text.

s9 Ryan (S.C.C.), supra note 1 at 16 (para. 41).

in Infa note 61 and accompanying text.

61 See for a general discussion of discovery abuse, A. Shanoff, "Discovery Abuse" (1991) Advocates" Soc. J. 9. Of course there are other ways to address plaintiffs' concerns of this sort. Unethical or abusive use of the information can and should be controlled, by professional bodies and the courts. 
adversely affected. ${ }^{62}$ The difficulties associated with this condition might lead to its subsequent setting aside, and in other cases might lead a court to decline to impose such a term. In this case, even the degree of protection of privacy accorded by restricting disclosure to "trustworthy professionals" would be lost.

The need for judicial screening of the documents was the essential point of departure of L'Heureux-Dubé J. She undertook the balancing of relevance against privacy in the exercise of the court's residual discretion to control discovery, but the balancing task she advocated was much the same as that described by the majority. She accepted that the interest in proper disposal of the litigation required production of relevant documents. On the other hand, Charter-protected interests in privacy and equality required a careful assessment of relevance. The substantial difference in the judgments lies in L'Heureux-Dubé J.'s holding that an informed assessment and appropriate balance requires judicial screening of documents. ${ }^{63}$

Why would the majority accept anything less? The rationale provided was that judicial screening of "numerous or lengthy documents may prove time-consuming, expensive and delay the resolution of the litigation." Allowing efficiency to override the plaintiff's privacy, where it does not qualify the defendant's disclosure, is not a balanced resolution of these competing interests. ${ }^{64}$ The plaintiff has at least as much reason as the defendant to maximize efficiency in pre-trial procedure. She can take steps to do this. The parties may be able to agree to some form of disclosure in the interests of saving time and money, and/or facilitating settlement. But if no such agreement is forthcoming, the defendant remains entitled to such production as is necessary to prepare his case, and the plaintiff should be entitled to respect for her privacy where production is not necessary. "Short cuts" at this point, and on this issue, which protect the defendant fully and the plaintiff only partly, are fundamentally unfair.

The requirement of judicial screening of documents in the civil context raises an additional issue that was not addressed in either of the judgments. In a criminal proceeding the application for production is made to the trial judge. ${ }^{65}$ Civil discovery, on the other hand, occurs well before any trial. The great majority of civil actions do

Law Society of Alberta, Alberta Code of Professional Conduct, c. 9, commentary G.1 and c. 7, commentary 6. Concern about the impact on the lawyer/client relationship was one of the reasons that led the Alberta Court of Appeal to reject an approach that would allow counsel, but not a litigant, to view documents for the purpose of arguing whether or not they were subject to Crown privilege (Pocklington Foods Inc. v. Alberta (Provincial Treasurer), [1993] 5 W.W.R. 710 at 719 20 (paras. 29-31) (per Côté J.A.) and 722 (para. 43) (per McClung J.A.)).

Ryan (S.C.C.), supra note 1 at 37 (para. 107). The records in the case spanned a therapeutic relationship of many years (from 1986 until at least 1993: see the Court of Appeal decision, at 687). Over this time one would expect that a significant portion of the information would not be relevant to the issues in the lawsuit (see the discussion of L'Heureux-Dube J. at 34 (paras. 94-96)). Canadian Bar Association, Report of the Canadian Bar Association - Task Force on Systems of Civil Justice (August 1996) [hereinafter "Task Force"], comments that lawyers from "across the country ranked the complexity and number of discoveries ... as key factors contributing to procedural delay" (at 43). 
not in fact go to trial, ${ }^{66}$ so the majority of the impact of Ryan will occur entirely outside the trial context.

As a result, this approach would require a significant additional commitment of judicial resources. It is not a matter of another task for a trial judge, who must in any event become fully apprised of the issues in the suit. Judges sitting in chambers are not typically required to become fully conversant with the issues and evidence involved in a civil action, but a detailed understanding would be required in order to engage in a sensitive balancing of disclosure and privacy rights. ${ }^{67}$ While a judicial commitment would be required, it is merited by the impact on privacy and equality where therapeutic records are sought in sexual assault cases. The screening rule should not automatically be extended to every instance of disclosure of private records; cases involving issues of sexual assault and counselling records have a unique impact on the rights to privacy and equality. ${ }^{68}$

\section{CONCLUSION}

In Ryan the Supreme Court of Canada attempted to affirm the "new" privacy and equality rights of victims of sexual assault, without upsetting the "old" balance of disclosure versus privacy concerns that arise in many forms of civil litigation, and notably in personal injury suits. In so doing, the majority can be accused of giving lip service only to the claims of sexual assault victims.

It is not surprising that the Court held that relevant documents necessary for the proper resolution of the litigation should be produced in the discovery process. The important public policy considerations that pertain to the production of medical records generally have application in this context. ${ }^{69}$ In view of the strong claim for disclosure, it is also not surprising that the Court continued its policy of declining to extend the categories of absolute privilege, preferring a form of "partial privilege" under which the protection of confidentiality accommodates such production as is necessary to "get at the truth and prevent an unjust verdict." 70

But while it held that counselling records are protected by a partial privilege, and that both privacy and equality should be considered in assessing whether on balance the defence is entitled to discover them, the majority ultimately ordered full disclosure of the records, and did not require judicial screening to separate the relevant from the irrelevant. Terms to protect confidentiality within the discovery process were also ordered, but these were not substantially different than would apply in any personal

Task Force, supra note 64 at 11, citing Ontario Civil Justice Review, First Report (1995) at 171, indicates that 95 percent to 97 percent of civil cases do not proceed to trial.

67 This may not pose as great a difficulty as it would have in the past. There is increasing use of case management in the civil courts (Task Force, ibid. at 37). A case management judge appointed to deal with all of the pre-trial issues in a civil suit will acquire the necessary familiarity with the case. Supra note 48 and accompanying text. Supra note 5. 
injury suit, or even in other forms of litigation. There was only one aspect of the decision which granted an additional degree of privacy within discovery, by barring the defendant from personally viewing the records. This condition of discovery creates its own harms, and will not always be possible to maintain. Further, it is not a sufficient protection of the plaintiff's privacy and equality rights. The dissenting approach, which would require judicial screening of the documents, better balances the competing interests. Judicial screening, while not mandated by the majority, is certainly permitted by it, and will hopefully be the preferred course in future cases. 